\title{
RIVER HYDROLOGY AND SUSPENDED SEDIMENT FLUX IN THE RED RIVER SYSTEM: IMPLICATION FOR ASSESSING SOIL EROSION AND SEDIMENT TRANSPORT/DEPOSITION PROCESSES
}

\author{
Thi Ha Dang ${ }^{1,2, *}$, Alexandra Coynel $^{2}$ \\ ${ }^{1}$ Ba Ria - Vung Tau University, 80 Truong Cong Dinh, VungTau, Vietnam \\ ${ }^{2}$ Université de Bordeaux, UMR CNRS 5805 EPOC, France \\ *Email: leha1645@yahoo.com
}

Received: 29 September 2015; Accepted for publication: 19 June 2016

\begin{abstract}
Based on a database of daily water discharge and daily suspended particulate matter concentrations along the Red River and at the outlet of the main tributaries (Da and Lo) during the 2005 - 2010 period, covering contrasting hydrological conditions, the water and sediment fluxes transported by the Red River system were determined. The results showed that only $21 \%$ of the discharge is derived from the upper Red River, $54 \%$ and $25 \%$ being derived from the Da and the Lo Rivers, respectively. In contrast, the distribution of suspended particulate matter (SPM) load is very different of that observed for water discharge: most SPM were eroded from the upstream catchment located in China (78 \%). Moreover, annual SPM fluxes (FSPM) showed a strong spatial variability between upstream watershed and the outlet of the river. The mean inter-annual FSPM was $30 \mathrm{Mt} / \mathrm{yr}$ (i.e. specific flux of $741 \mathrm{t} / \mathrm{km}^{2} / \mathrm{yr}$ ) at the Lao Cai site, $38 \mathrm{Mt} / \mathrm{yr}$ (i.e. $792 \mathrm{t} / \mathrm{km}^{2} / \mathrm{yr}$ ) at the Phu Tho gauging site, $29 \mathrm{Mt} / \mathrm{yr}$ (i.e. $193 \mathrm{t} / \mathrm{km}^{2} / \mathrm{yr}$ ) at the Son Tay gauging station. Its values were $4.1 \mathrm{Mt} / \mathrm{yr}$ (i.e. $80 \mathrm{t} / \mathrm{km}^{2} / \mathrm{yr}$ ) and $6.6 \mathrm{Mt} / \mathrm{yr}$ (i.e. $191 \mathrm{t} / \mathrm{km}^{2} / \mathrm{yr}$ ) for the $\mathrm{Da}$ and Lo rivers, respectively. Between the Lao Cai and Phu Tho sites, both erosion and sedimentation processes occurred together, but strongly depended on the hydrological conditions. Between the Phu Tho and Son Tay sites, the important loss of SPM flux suggested a dominant deposition process in the floodplain during high water before the delta. These results proved the complex processes of erosion/sedimentation occurring on the Red River watershed.
\end{abstract}

Keywords: Red River, erosion, suspended particulate matter concentrations, fluxes, spatial variability, transport, deposition.

\section{INTRODUCTION}

The fluvial transfer of sediment from the land to the coastal areas and/or the ocean reflects the denudation of the continents and contributes to new depositional environment $[1,2]$. 
Furthermore, quantifying accurately the sediment delivery to the ocean is fundamental to (i) establish global biogeochemical cycles (e.g. for the carbon cycle [1, 3]), (ii) understand many physical processes (e.g. evolution of landscape and coastal landforms [2, 4]) and (iii) evaluate its potential role as a pathway for pollutants from terrestrial to coastal and marine systems $[4,5]$. Clarifying the variation of sediment flux through the riverine sediment routing system is necessary to assess the mechanism and source of riverine sediment flux load to the ocean [6]. The understanding of the hydro-sedimentary transfer processes are also essential for improved sustainable management of continental surfaces where human societies are concentrated.

The Red River (China/Vietnam) plays an important role in the economic, cultural and political life of the Vietnamese people. Based on a long-term observation (1960-2008), the mean annual river sediment transport in the Red River was estimated to $90 \mathrm{Mt} / \mathrm{yr}$ and the temporal variability (24-200 Mt/yr) was attributed to hydrological conditions and anthropogenic activities (e.g. reduction by half due to the commissioning of a major dam reservoir [2]). However, the previous study of Dang et al. (2010) $[2,7,8]$ had not localised sediment sources and identified physical processes because it relied on daily water discharges and SPM concentrations measured at the outlet of the River System and the upstream limit of the dynamic tide, just before the Delta System. This present study is based on recent daily measurements collected at different strategic sites in the Red River System between 2005 and 2010. The objectives of this study are to: (i) quantify the SPM fluxes along the Red River system, (ii) analyse the spatial variability of sediment transport in order to identify the sources of water and SPM flux, and (iii) clarify physical processes of erosion, transport and deposition of sediment by proposing a erosion/transport model for the Red River basin.

\section{MATERIALS AND METHODS}

\subsection{Area descriptions}

The Red River system, located in South-East Asia, has a total watershed area of $169000 \mathrm{~km}^{2}, 50.3 \%$ of which in Vietnam, $48.8 \%$ in situated in China and $0.9 \%$ is situated in Laos and includes a fertile and densely populated delta plain $\left(14,000 \mathrm{~km}^{2}\right)$. The Red River originates from the mountainous area of Yunnan Province in China, flows $1200 \mathrm{~km}$ southeastward and then flows through seven Vietnamese provinces before flowing into the Gulf of Tonkin in the South China Sea (Figure 1). The main tributaries of the Red River are the Da River, on the right bank, and the Lo River, on the left bank (Figure 1).

The Red River basin is characterized by two distinct seasons: the wet season from May to October and the dry season from November to April, due to the South West monsoon in summer and the North East monsoon in winter, respectively. The summer season is warm and very humid, with mean temperatures ranging from $27^{\circ} \mathrm{C}$ to $29^{\circ} \mathrm{C}$ whereas the winter season is cool and dry with mean monthly temperatures ranging from $16{ }^{\circ} \mathrm{C}$ to $21{ }^{\circ} \mathrm{C}$ [9]. The average annual rainfall in the Red River System is $1600 \mathrm{~mm}$, with $85 \%$ - $95 \%$ of this falling during the summer season [10]. 


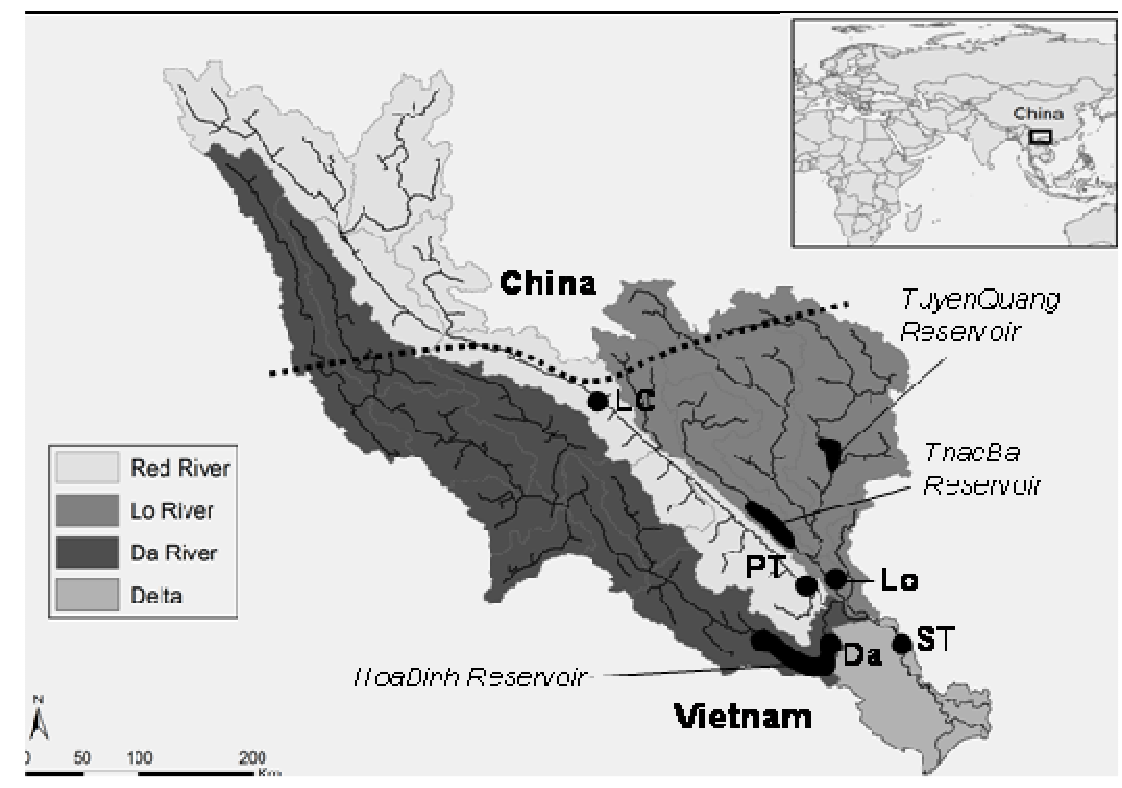

Figure 1. Description of the Red River system and location of study sites.

\subsection{Data and methodology}

Daily monitoring was performed by the Vietnamese Institute of Metrology, Hydrology and Environment (IMHE) at five strategic permanent observation sites from 2005 to 2010 (Figure 1):

(1) the Lao Cai gauging site (simplified by LC) corresponds to the entry of the Red River in Vietnam and represents river borne material derived from the Upper Red River draining from China;

(2) the Phu Tho gauging site (simplified by PT) is situated at the outlet of the Red River before the confluence with the Da and the Lo Rivers;

(3) the HoaBinh gauging site (simplified by Da) is located at the outlet of the Da River and integrates material derived from the Da system after the HoaBinh Reservoir;

(4) the VuQuang gauging site (simplified by Lo) is located at the outlet of the Lo River;

(5) the Son Tay gauging site (simplified by ST), near Hanoi, is located at the downstream of the confluence with the three main tributaries (Red, Da and Lo Rivers) and at the upstream limit of the dynamic tide; this site is considered to be the outlet of the Red River system and the entry point to the Red River Delta.

Daily SPM concentrations were manually collected one time per day and filtered using preweighted filters according to the Vietnamese national standard criteria: during low water levels, daily water samples were collected at $20-30 \mathrm{~cm}$ from the surface water and $4 \mathrm{~m}$ from the right riverbank; during high water discharges, daily samples were collected from depth-integrated vertical profiles. Daily water discharges are estimated from daily measurements of river stage and the stage-discharge rating curve (MONRE, 1997-2004).

\subsection{Annual reference SPM flux}


Based on the daily database of water discharge and SPM concentrations, the annual SPM fluxes were calculated by summing the daily SPM fluxes which are established by multiplying the daily water discharge with the corresponding SPM concentration:

$$
\mathrm{F}_{\mathrm{SPM} a}=\sum_{i=1}^{n} \mathbf{F}_{\mathrm{SPMd}} \text { with } \mathrm{F}_{\mathrm{SPMd}}=[S P M]_{d} \times Q_{d}
$$

where: $\mathrm{F}_{\mathrm{SPM} a}$ is the annual SPM flux (expressed in $\mathrm{t} / \mathrm{yr}$ ); $\mathrm{F}_{\mathrm{SPM} d}$ are the daily SPM fluxes (t/day); $[\mathrm{SPM}]_{d}$ and $\mathrm{Q}_{d}$ are the daily SPM concentrations $(\mathrm{mg} / \mathrm{l})$ and water discharges $\left(\mathrm{m}^{3} / \mathrm{s}\right)$, with $\mathrm{n}=365$ or 366 .

\section{RESULTS AND DISCUSSIONS}

\subsection{Variability of the water discharges in the Red River System}

Based on daily water discharge measurements during 6 years (2005-2010), two main hydrological features are observed at the five gauging sites which reflect the rivers' response to seasonal rainy distribution and runoff: the dry season, from November to April, is characterized by low water discharges whereas the rainy season, from May to October, is characterized by high water discharges, as classically observed for typical wet river systems with a pronounced monsoon (Figure 2, [11]). As a consequence, daily water discharges in the main channel of the Red River varied between $123 \mathrm{~m}^{3} / \mathrm{s}$ to $5500 \mathrm{~m}^{3} / \mathrm{s}$ (temporal variation factor $=45$ ) at the Lao Cai site, between $132 \mathrm{~m}^{3} / \mathrm{s}$ to $10100 \mathrm{~m}^{3} / \mathrm{s}$ (factor $=76$ ) at the Phu Tho site and between $730 \mathrm{~m}^{3} / \mathrm{s}$ to $14600 \mathrm{~m}^{3} / \mathrm{s}($ factor $=20)$ at the Son Tay site. In the two major tributaries, daily water discharge ranged from 221 to $10200 \mathrm{~m}^{3} / \mathrm{s}$ (factor = 46) for the Da River and from 92 to $6780 \mathrm{~m}^{3} / \mathrm{s}$ (factor = 74) for the Lo River.

The annual water discharges highly varied from one year/site to another (Table 1). The annual water discharges ranged from 363 to $638 \mathrm{~m}^{3} / \mathrm{s}$ at Lao Cai, from 568 to $900 \mathrm{~m}^{3} / \mathrm{s}$ at Phu Tho and from 2724 to $4095 \mathrm{~m}^{3} / \mathrm{s}$ at Son Tay for the Red River System. Concerning both tributaries, annual values ranged from 1551 to $1962 \mathrm{~m}^{3} / \mathrm{s}$ and from 576 to $1172 \mathrm{~m}^{3} / \mathrm{s}$ for the Da and Lo Rivers, respectively. The annual water discharges measured at the Son Tay site are similar to the sum of the corresponding annual water discharge of the three major tributaries (the Red River at Phu Tho, the Da and Lo Rivers) except for the 2003 year at which the sum of water of three tributaries was higher (>17\%) than that of the Red River at the Son Tay site. The Red River System can be considered as one balanced fluvial system for freshwater fluxes (i.e. water inputs $\sim$ water outputs).

The mean annual water discharges for the $2005-2010$ period were $542 \mathrm{~m}^{3} / \mathrm{s}, 678 \mathrm{~m}^{3} / \mathrm{s}$ and $3171 \mathrm{~m}^{3} / \mathrm{s}$ for the Red River at Lao Cai, Phu Tho and Son Tay sites and $1717 \mathrm{~m}^{3} / \mathrm{s}$ and $809 \mathrm{~m}^{3} / \mathrm{s}$ for the Da and Lo Rivers, respectively. The Da River plays a major role of water source for the Red River system, contributing more than half of the total water discharge. The freshwater derived from the Red River at Phu Tho and the Lo River represented, for the study period, 21 and $25 \%$, respectively. The sub-basin have the following mean specific discharge rate (i.e. water discharge per unit area of the sub-basin): Da River $\left(33 \mathrm{l} / \mathrm{s} / \mathrm{km}^{2}\right)>\operatorname{Lo} \operatorname{River}\left(23 \mathrm{l} / \mathrm{s} / \mathrm{km}^{2}\right) \sim$ Red River at Son Tay $\left(21 \mathrm{l} / \mathrm{s} / \mathrm{km}^{2}\right)>$ Red River at Phu Tho $\left(14 \mathrm{l} / \mathrm{s} / \mathrm{km}^{2}\right) \sim$ Red River at Lao Cai $\left(13.5 \mathrm{l} / \mathrm{s} / \mathrm{km}^{2}\right)$. These results showed that the specific discharges of the Red River are comparable to the Mekong River ( 19 1/s/km² [14]) and lower than the Ganges - Brahmaputra System ( $35 \mathrm{l} / \mathrm{s} / \mathrm{km}^{2}$ [12]), except for the Da River. 

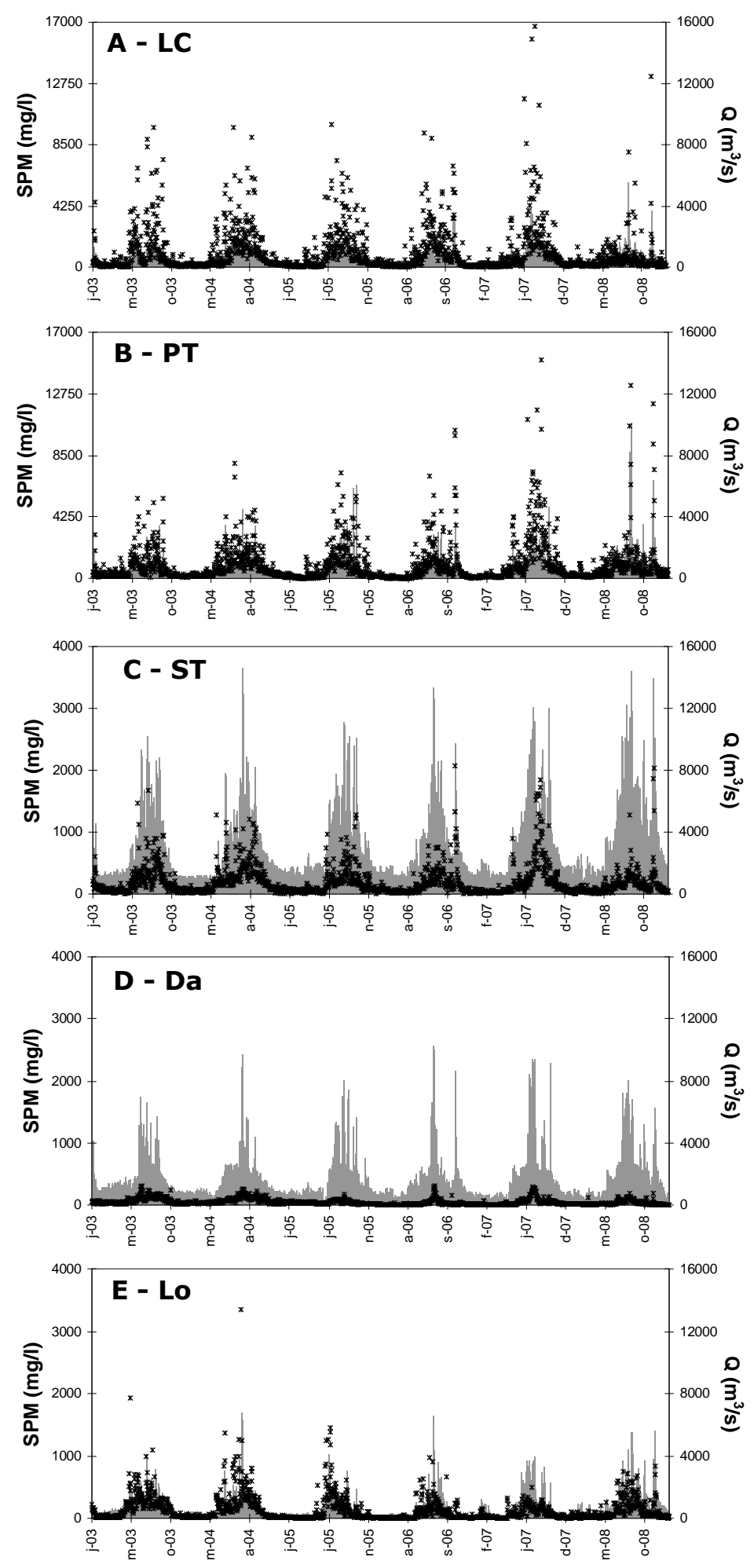

Figure 2. Evolution of daily SPM concentrations (SPM, mg/l) and daily water discharge (Q, $\left.\mathrm{m}^{3} / \mathrm{s}\right)$ for the Red River at the Lao Cai (A), Phu Tho (B), Son Tay (C), and at the outlet of the Da River (D) and Lo River (E) during the 2005-2010 period. 
Table 1. Flow and SPM transport regime characteristics for the Red River System at five stations (Q-water discharge in $\mathrm{m}^{3} / \mathrm{s}$; SPM: suspended particulate matter in $\mathrm{mg} / \mathrm{l}$; FSPM: annual of SPM flux in $10^{6} \mathrm{t}$, $\mathrm{Y}$ : specific erosion yields in $\mathrm{t} / \mathrm{km}^{2} / \mathrm{yr}$; Hyd.: Hydrologycal condition).

\begin{tabular}{|c|c|c|c|c|c|c|c|}
\hline Year & $\begin{array}{c}Q \\
\mathrm{~m}^{3} / \mathrm{s}\end{array}$ & $\begin{array}{c}\text { SPM } \\
(\mathrm{mg} / \mathrm{l})\end{array}$ & $\begin{array}{c}F_{S P M} \\
\left({ }^{*} 10^{6} t\right)\end{array}$ & $\begin{array}{c}\mathrm{Y} \\
\left(\mathrm{t} / \mathrm{km}^{2} / \mathrm{yr}\right)\end{array}$ & Hyd. & $\underset{(\min -\max )}{Q}$ & $\begin{array}{c}\text { SPM } \\
\text { (min-max) }\end{array}$ \\
\hline \multicolumn{8}{|c|}{ Red River at LaoCai } \\
\hline 2005 & 608 & 931 & 29.6 & 722 & Mean $(+10 \%)$ & $222-1660$ & $18-9667$ \\
\hline 2006 & 631 & 1,070 & 34.3 & 837 & Mean $(+14 \%)$ & $184-2260$ & $44-9672$ \\
\hline 2007 & 420 & 937 & 22.7 & 554 & Dry (-24\%) & $128-2160$ & $25-9870$ \\
\hline 2008 & 363 & 950 & 22.2 & 541 & Dry (-35\%) & $123-3100$ & $27-9340$ \\
\hline 2009 & 592 & 1,112 & 46.9 & 1,144 & Mean (+7\%) & $130-3820$ & $22-16700$ \\
\hline 2010 & 638 & 536 & 22.2 & 541 & Wet $(+15 \%)$ & $127-5500$ & $6.9-13200$ \\
\hline \multicolumn{8}{|c|}{ Red River at PhuTho } \\
\hline 2005 & 590 & 697 & 20.7 & 431 & Dry (-22\%) & $167-3240$ & $53-5528$ \\
\hline 2006 & 652 & 931 & 30.9 & 644 & Mean (-13\%) & $146-4500$ & $159-7980$ \\
\hline 2007 & 668 & 777 & 33.1 & 690 & Mean $(-11 \%)$ & $140-6080$ & $21-7250$ \\
\hline 2008 & 568 & 734 & 27.6 & 575 & Dry $(-25 \%)$ & $144-3650$ & $15-10200$ \\
\hline 2009 & 693 & 1,265 & 56.4 & 1,175 & Mean $(+8 \%)$ & $132-4670$ & $36-15100$ \\
\hline 2010 & 900 & 835 & 60 & 1,250 & Wet $(+20 \%)$ & $196-10100$ & $90-13300$ \\
\hline \multicolumn{8}{|c|}{ Red River at SonTay } \\
\hline 2005 & 2,724 & 189 & 25.8 & 172 & Dry $(-23 \%)$ & $1030-10200$ & $4.1-1673$ \\
\hline 2006 & 2,955 & 232 & 33.2 & 221 & Dry (-23\%) & $870-14600$ & $5.3-1270$ \\
\hline 2007 & 3,097 & 163 & 25.6 & 171 & Mean (13\%) & $987-11100$ & $2.1-1720$ \\
\hline 2008 & 2,850 & 160 & 23.6 & 158 & Dry $(-20 \%)$ & $870-13300$ & $6.2-2070$ \\
\hline 2009 & 3,303 & 214 & 34.8 & 232 & Mean $(7 \%)$ & $830-12100$ & $6.6-1850$ \\
\hline 2010 & 4,095 & 144 & 30.2 & 201 & Wet $(+15 \%)$ & $730-14400$ & $2.4-2350$ \\
\hline \multicolumn{8}{|c|}{ Da River } \\
\hline 2005 & 1,733 & 74 & 5.5 & 107 & Mean (+3\%) & $589-6920$ & $16-309$ \\
\hline 2006 & 1,650 & 75 & 5.3 & 104 & Mean $(-2 \%)$ & $283-9650$ & $167-264$ \\
\hline 2007 & 1,628 & 38 & 2.6 & 51 & Mean (-4\%) & $238-8060$ & $4.1-178$ \\
\hline 2008 & 1,551 & 26 & 2.7 & 53 & Mean (-8\%) & $317-10200$ & $0.5-306$ \\
\hline 2009 & 1,777 & 43 & 5.4 & 106 & Mean (+5\%) & $221-9440$ & $0.5-296$ \\
\hline 2010 & 1,962 & 31 & 3.2 & 63 & Wet $(+16 \%)$ & $265-8020$ & $1.3-195$ \\
\hline \multicolumn{8}{|c|}{ Lo River } \\
\hline 2005 & 878 & 170 & 8 & 235 & Dry $(-16 \%)$ & $195-4130$ & $15-1929$ \\
\hline 2006 & 764 & 186 & 10.6 & 312 & Dry (-27\%) & $165-6780$ & $13-3350$ \\
\hline 2007 & 636 & 119 & 5.4 & 159 & Dry (-39\%) & $102-4110$ & $6.5-1450$ \\
\hline 2008 & 576 & 83 & 3.5 & 103 & Dry (-45\%) & $92-6530$ & $2.0-979$ \\
\hline 2009 & 831 & 74 & 3.7 & 109 & Dry (-21\%) & 99 - 3970 & $2.2-491$ \\
\hline 2010 & 1,172 & 125 & 8.6 & 253 & Mean $(+12 \%)$ & $238-5630$ & $6.6-842$ \\
\hline
\end{tabular}

\subsection{Variability of the SPM concentrations in the Red River System}

The evolution of SPM concentrations at the five sub-basins of the Red River showed high seasonal and inter-annual variations which are closely linked to the variability of water discharges with the highest values observed during the rainy season (Figure 2). The daily SPM concentrations of the Red River ranged from 6.9 to $16,700 \mathrm{mg} / \mathrm{l}$, from 15 to $15,100 \mathrm{mg} / \mathrm{l}$ and from 2.1 to 2,350 mg/l at the Lao Cai, Phu Tho and Son Tay sites, respectively. Concerning both tributaries, the daily values varied between 0.5 and $309 \mathrm{mg} / \mathrm{l}$ for the Da River and between 2.0 and 3,350 $\mathrm{mg} / \mathrm{l}$ for the Lo River. The SPM concentration variability, expressed as the ratio between the maximum and minimum SPM concentrations ranged from 618 (for the Da River) to 
2420 (for the Red River at the Lao Cai site); this variability range is one to two orders of magnitude higher than that for the water discharges (see section 3.1).

The mean SPM concentrations of the Red River at Lao Cai, Phu Tho and Son Tay sites in the dry season were 275,306 , and $77 \mathrm{mg} / \mathrm{l}$, respectively. These mean values can increase up to $1,555,1,430$ and $290 \mathrm{mg} / \mathrm{l}$ in the rainy season, for the Red River at Lao Cai, Phu Tho and Son Tay sites, respectively. For both tributaries, the mean SPM concentrations were $22 \mathrm{mg} / \mathrm{l}$ and 32 $\mathrm{mg} / \mathrm{l}$ during the dry season and were 72 and $217 \mathrm{mg} / \mathrm{l}$ during the rainy season in the Da and Lo Rivers, respectively.

\subsection{Variability of the annual SPM fluxes and specific erosion yields: localisation of sediment sources}

The main branch Red River annually carried very important SPM loads ranging from $22.2 \times 10^{6} \mathrm{t} / \mathrm{yr}$ to $46.9 \times 10^{6} \mathrm{t} / \mathrm{yr}$ at Lao Cai, from $20.7 \times 10^{6} \mathrm{t} / \mathrm{yr}$ to $60 \times 10^{6} \mathrm{t} / \mathrm{yr}$ at Phu Tho and from $23.6 \times 10^{6} \mathrm{t} / \mathrm{yr}$ to $34.8 \times 10^{6} \mathrm{t} / \mathrm{yr}$ at Son Tay. For the study period, the inter-annual SPM fluxes were estimated at $30 \times 10^{6} \mathrm{t} / \mathrm{yr}, 38 \times 10^{6} \mathrm{t} / \mathrm{yr}$ and $29 \times 10^{6} \mathrm{t} / \mathrm{yr}$ at the Lao Cai, Phu Tho and Son Tay sites, respectively (Table 1). The high annual SPM flux estimated at the Lao Cai site (i.e. the entry of the Red River in Vietnam) tend to demonstrate that a significant sediment supply comes from the upstream watershed located in China. The annual SPM fluxes from the Da and Lo Rivers were clearly lower than that of the main branch with inter-annual SPM fluxes accounting for $4.1 \times 10^{6} \mathrm{t} / \mathrm{yr}$ and $6.6 \times 10^{6} \mathrm{t} / \mathrm{yr}$, respectively.

The sum of the inter-annual SPM fluxes transported by the three main branches of the Red River System (Red River at Phu Tho, Da and Lo) into the Red River Delta was calculated. If the water discharge into the Red River Delta is derived from the Da River (superior to $50 \%$ ), SPM flux into the Red River Delta is dominated by the Red River (at Phu Tho) with the contribution of $78 \%$ (varied from 61 to $86 \%$ ). The Da and Lo River contributed $8 \%$ and $14 \%$ of SPM flux into the Red River Delta, respectively. However, the sum of the mean annual fluxes from three main branches is higher than the mean annual flux at the Son Tay site suggesting significant sedimentation before the entry to the Delta. This sedimentation phenomenon is more developed in section 3.3.

\subsection{Erosion / Transport Model for the Red River System}

\section{Erosion and transport processes in the middle section of the Red River System}

If the inter-annual SPM transport on the $2005-2010$ period measured at the Lao Cai is lower than that of the Phu Tho site (30 versus $\left.38 \times 10^{6} \mathrm{t} / \mathrm{yr}\right)$, SPM flux can show significant difference at the annual scale. For example, the annual SPM flux at Lao Cai was slightly higher than that at Phu Tho in 2005 and 2006, when the annual water discharge at the two sites were comparable (Table 1). In contrast, in the years 2007, 2008, 2009 and 2010, when the annual water discharges at the Phu Tho site were higher than those at Lao Cai, the annual SPM fluxes measured at Phu Tho were superior to those at Lao Cai (Table 1). This phenomenon is more marked in 2008 with a SPM flux at Phu Tho which is 3 times higher than that at Lao Cai.

Based on this observation, we proposed two contrasting processes of erosion/remobilisation and sedimentation occurring along the Red River System between the Lao Cai and Phu Tho sites, depending on the hydrological conditions (Figure 3): 
- Case 1: when annual water discharges at the Lao Cai and Phu Tho sites are similar, the annual SPM flux have decreased between the Lao Cai and Phu Tho section, reflecting the sedimentation/deposition process between two sites and estimated at $\sim 6 \times 10^{6} \mathrm{t} / \mathrm{yr}$ (example 2005-2006, Figure 3A). This sedimentation may be explained by a limitation of the sediment transport may be due to the decrease of the channel slope. This result demonstrates that the slope erosion is the dominant process occurring in the upstream system and a decrease of erosion rate is observed downstream as observed in another humid tropical watershed in Costa Rica [13];

- Case 2: when the annual water discharge at Phu Tho is higher than that at Lao Cai, the annual SPM flux at Phu Tho is also higher, reflecting both erosion/re-mobilisation processes between the Lao Cai and Phu Tho section (example 2007-2008, Figure 3B) and suggests preponderant channel erosion. This increase is consequent to runoff occurring in this section due to the rainfall in the middle part of the Red System.

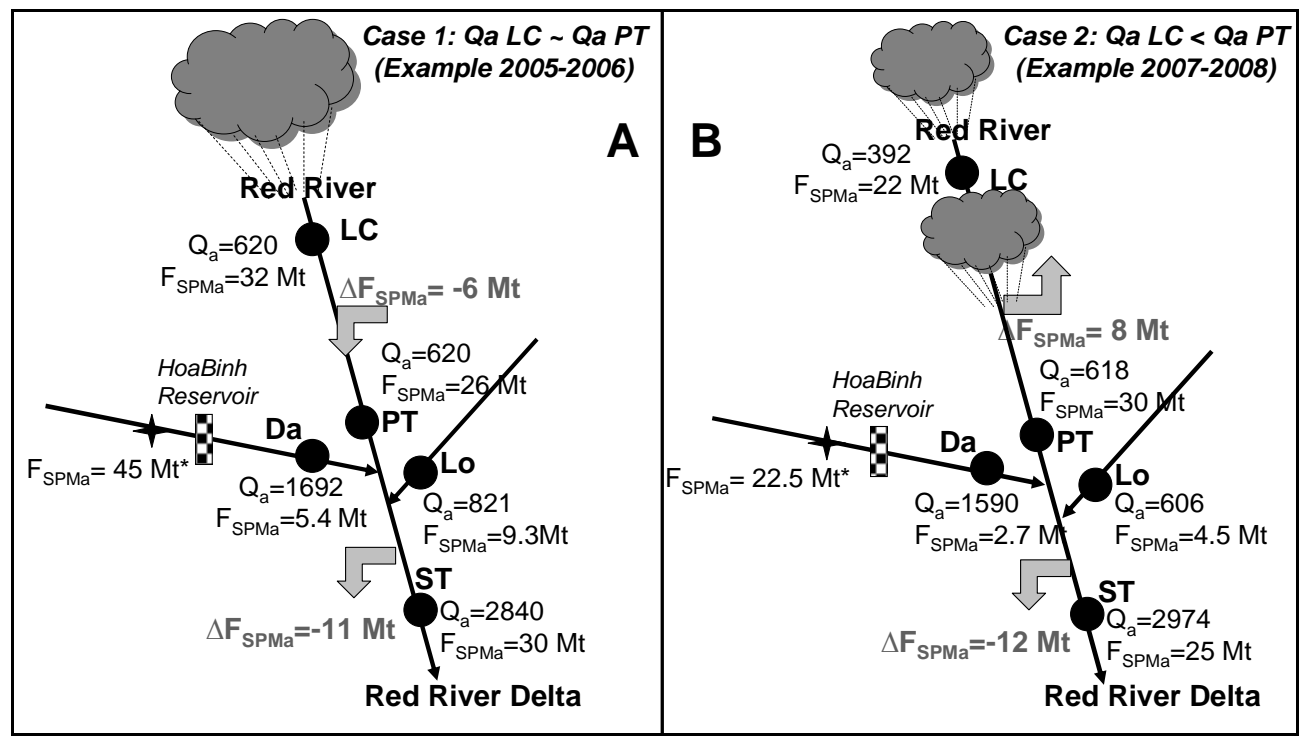

Figure 3. Model of Water discharge (Q in $\mathrm{m}^{3} / \mathrm{s}$ ) and SPM flux transported by the Red River between Lao Cai and Son Tay, showing (A) the deposition case during 2005-2006 ( $\square$ ) or (B) the erosion case during 2007-2008 ( $\square$ ). (*[2]).

\section{Deposition processes in the low reach of the Red River System}

Unlike the conservation of water discharge between upstream (i.e. at the outlet of the Red, $\mathrm{Da}$ and Lo Rivers) and downstream from the confluence of the three main tributaries (i.e. the Red River at Son Tay site, and see the section 3.1), the SPM flux of the Red Rivers at Son Tay is always lower than the sum of SPM flux of three rivers (generally from 8 to $42 \mathrm{Mt}$; Table 1), showing an important loss of suspended matter in this river section. This loss of material along the lower courses of the Red River has been already observed in other rivers in the world, like the Negro, Tapajos and Xingu rivers in the Brazilian Amazon [14], the Indus River [15], the Rio Itenez-Guopore River in Bolivia [16], the Yellow River [17] and the Mississippi River [18]. This phenomenon has been attributed to three main processes: diffuse riverbank settling, channelized floodplain sedimentation and/or riverbed deposition [19] . 
The inter-annual duration curves (e.g. the mean cumulative water and SPM fluxes as a function of the time) were established for the upstream (Da, Lo and Red River) and the downstream (Son Tay) to clearly identify process involved in SPM transport (Figure 4). We observed that the cumulative water flux at the Son Tay site was similar with the cumulative water flux from the three main tributaries. The cumulative SPM flux measured at the Son Tay site was comparable with the sum of the three tributaries for the November - April period, corresponding to the dry season, while a great difference was found during the May to October period, corresponding to the rainy season. In fact, during the rainy season, the sum of fluxes from the three main tributaries is higher than the flux measured at Son Tay. The difference between these two fluxes highlighted a large sediment loss occurring during this period attributed to sediment deposition on the low reach, just before the delta.
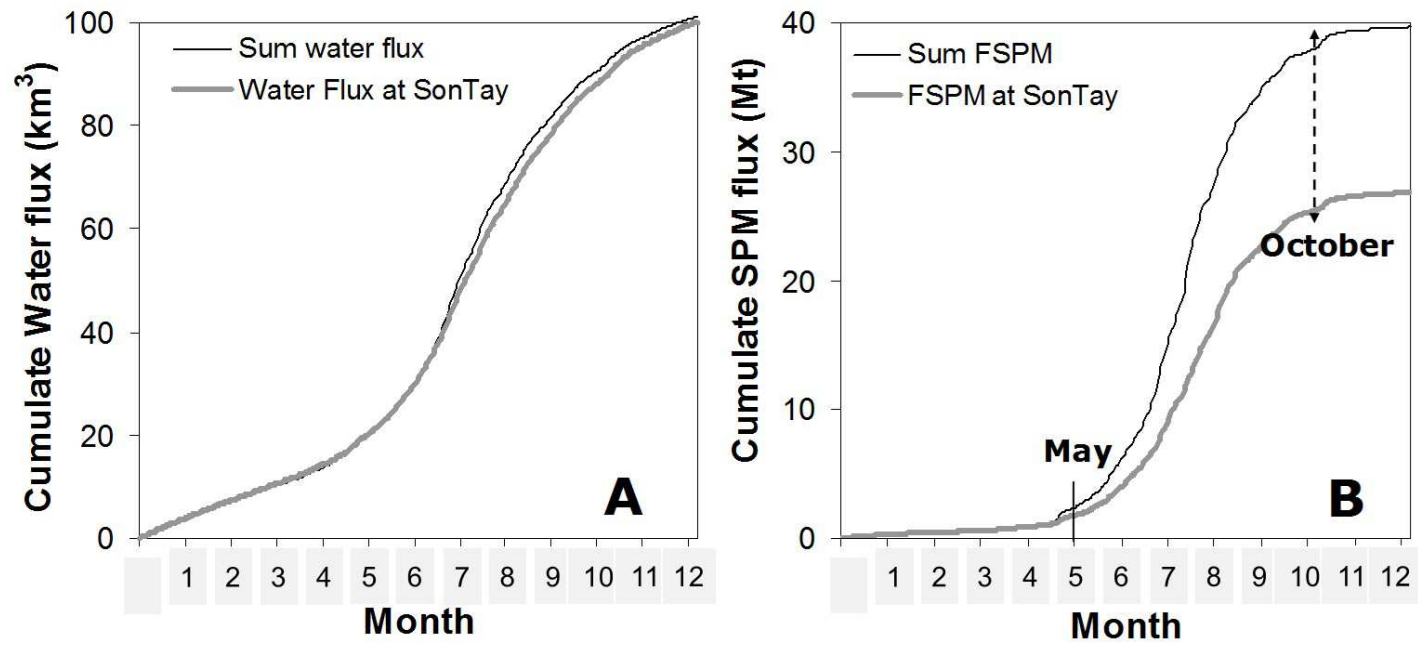

Figure 4. (A) Cumulative Water flux v.s time and (B) Cumulative Suspended particulate matter flux vs. time; Comparison between the water and SPM fluxes measured at the Son Tay site (in grey) and the water and SPM fluxes calculated as the sum of the supplies from the Red River at Phu Tho and the Da and

Lo Rivers ("Sum"; in black).
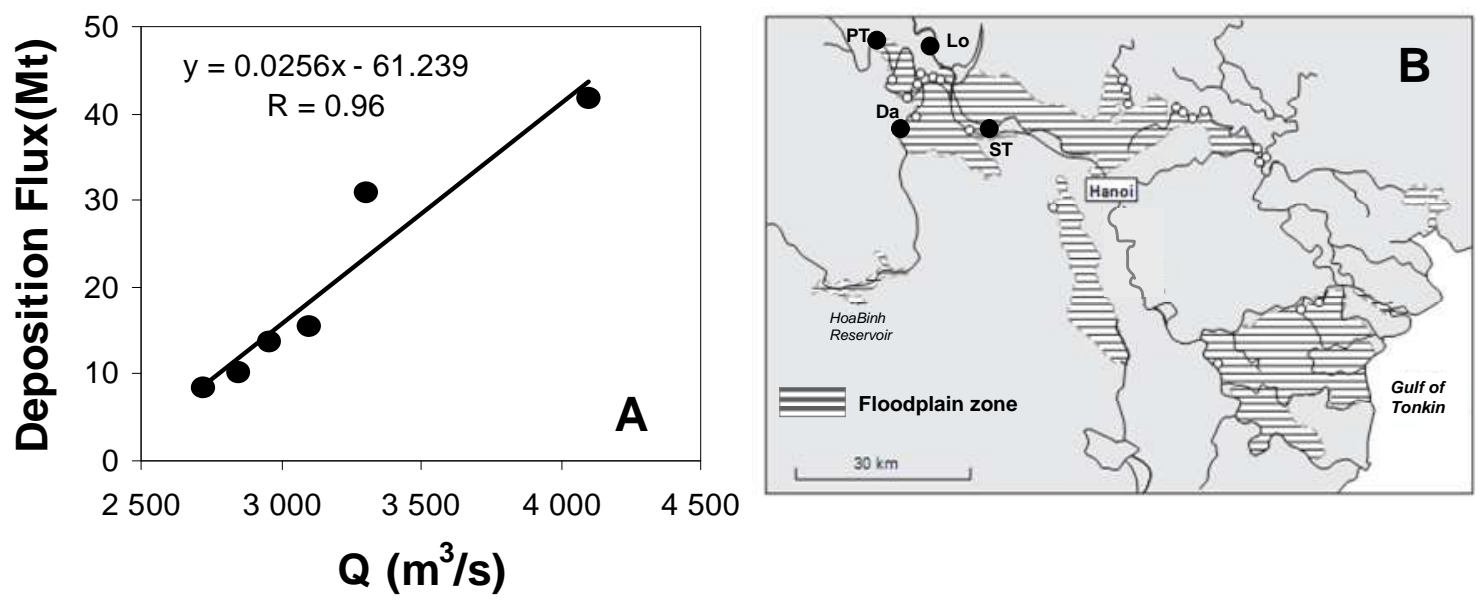

Figure 5. (A): Relationship between the annual deposition SPM flux and the annual water discharge of the Red River at the Son Tay gauging station for the 2005-2010 period; (B): Floodplain map of the Red River Delta (Source: [20]). 
Moreover, a very good relationship was observed between the deposited SPM flux and the annual discharge $(\mathrm{R}=0.96$; Figure $5 \mathrm{~A})$, showing that the water discharge plays an important role on alluvial deposition flux along the Red River (between the outlets of main rivers and the Son Tay site) and clearly reflects substantial sedimentation on the floodplains during the rainy season and high water discharges (Figure 5B).

\section{CONCLUSIONS AND PERSPECTIVES}

Annual water discharge measured at the outlet of the three main tributaries and at the outlet of the System (just before the entry to the Delta) showed that the Red River is one balanced fluvial for freshwater with $50 \%$ water flux delivered from the Da River. The annual SPM fluxes showed a strong spatial variation between the upstream watershed and the outlet of the river. In addition, the source of SPM into the Red River delta was determined: the majority of the SPM comes from the upstream catchment in China. The inter-annual SPM fluxes in the Red River were $30 \mathrm{Mt} / \mathrm{yr}$ at the Lao Cai site, $38 \mathrm{Mt} / \mathrm{yr}$ at the Phu Tho site and $29 \mathrm{Mt} / \mathrm{yr}$ at the Son Tay site.

Finally, SPM flux measured along the Red River and at the outlet of the Da and Lo proved the complex processes of erosion/sedimentation occurring on the basin. Between the Lao Cai and Phu Tho sites, both erosion and sedimentation processes occurred together, but strongly depended on the hydrological condition. Between the Phu Tho and Son Tay sites, the important loss of SPM flux suggested a dominant deposition process in the floodplain during high water before the delta. Further erosion studies (quantification and modelisation) should at a minimum use and analyse SPM load with a long-term observation to better understand SPM transport dynamic.

Acknowledgements. This work was supported by the INSU-ST River-Sông program, the Institute of Meteorology, Hydrology and Environment (IMHE, Hanoï, Vietnam) and the International Water Management Institute (IWMI-IRD).

\section{REFERENCES}

1. Meybeck M. - Global analysis of river systems: from Earth system controls to Anthropocene syndromes, The Royal Society (2003) 20pp.

2. Coynel A., Seyler P., Etcheber, H., Meybeck M., Orange D. - Spatial and seasonal dynamics of total suspended sediment and organic carbon species in the Congo River, Global Biogeochemical Cycles 19 (2005) 1-17.

3. Dang T. H., Coynel A., Orange D., Blanc G., Etcheber H., Le L. A. - Long-term monitoring (1960-2008) of the river-sediment transport in the Red River Watershed (Vietnam): temporal variability and dam-reservoir impact, Science of the Total Environment 408 (2010) 4654-4664.

4. Dang T. H, Coynel A. - Estimating the sampling frequency and accuracy of sediment flux in a large asian river: the Red River (China/Vietnam), Journal of Science and Technology 53 (2015) 194-204.

5. Dang T. H., Coynel A., Orange D., Blanc G., Etcheber H., Schafer J., Le L. A. - Erosion and impact of human disturbance on sediment transport in the Red River, Vietnam, Geochimica et Cosmochimica Acta 73 (2009) p. A260.

6. Dang T. H., Coynel A., Orange D., Blanc G., Etcheber H., Schafer J., Le L. A. Estimating river - Discharges in the Red River (Vietnam) using rating curves and impact 
of reservoirs on transport, Biogeomon 2009, the 6th international symposium on ecosystem behaviour, University of Helsinki, Finland.

7. Dang T. H., Coynel A., Orange D., Blanc G., Etcheber H., Le L. A. - Contamination of arsenic in the Red River watershed (China/Vietnam): Distribution, source and flux, One Century of the Discovery of Arsenicosis in Latin America (1914-2014): As 2014 Proceedings of the 5th International Congress on Arsenic in the Environment.

8. Le T. P. Q., Garnier J., Gilles B., Sylvain T., Chau V. M. - The changing flow regime and sediment load of the Red River, Vietnam, Journal of Hydrology 334 (2007) 199-214.

9. Dang T. H., Coynel A. - Assessment of arsenic contamination in the Red river: High resolution monitoring coupled with spatial analysis by GIS, Journal of Science and Technology 51 (2013) 787-797.

10. Dang T. H., Coynel A. - Seasonal variability of particulate organic carbon (POC) in a large Asian tropical river: The Red river (China/Vietnam), Journal of Science and Technology 51 (2013) 325-335.

11. Kripalani R.H., Kulkarni A. - The relationship between some large-scale atmospheric parameters and rainfall over Southeast Asia: A comparison with features over India, Theoretical and Applied Climatology 59 (1998) 1-11.

12. Krishnaswamy J., Richter D. D., Halpin P. N., Hofmockel M. S. - Spatial patterns of suspended sediment yield in a humid tropical watershed in Costa Rica, Hydrological Processes 15 (2001) 2237-2257.

13. Nishat B., Bahman S. M. - Water resources modelling of the Ganges-BrahmaputraMeghna river basins using satellite remote sensing data, Journal of the American Water Resources Association 45 (2009) 1313-1327.

14. Walling D. E., Fang D. - Recent trends in the suspended sediment loads of the world's rivers, Global and Planetary Change 39 (2003) 111-126.

15. Milliman J. D., Quraishee G. S., Beg M. A. A. - Sediment discharge from the Indus River to the ocean: past, present and future, In: Haq, B.U. and Milliman, J.D. (eds): Marine Geology and Oceanography of the Arabian Sea and Coastal Pakistan. Van Nostrand Reinhold Co, New York (1994) pp. 65-70.

16. Guyot J. L., Filizola N., Quintanilla J., Cortez J. - Dissolved solids and suspended sediment yields in the Rio Madeira basin, from the Bolivian Andes to the Amazon, IAHSAISH Publication 236 (1996) 55-63.

17. Shi C., Zhang D. D. - A sediment budget of the lower Yellow River, China, over the period from 1855 to 1968, Geografiska Annaler, Series A: Physical Geography 87 (2005) 461-471.

18. Meade R. H., Moody J. A. - Causes for the decline of suspended-sediment discharge in the Mississippi River system, 1940-2007, Hydrological Processes 24 (2010) 35-49.

19. Horowitz A. J., Stephens V. C. - The effects of land use on fluvial sediment chemistry for the conterminous U.S. - Results from the first cycle of the NASQAN Program: Trace and major elements, phosphorus, carbon, and sulphur, Science of the Total Environment 400 (2008) 290-314.

20. Gilard O. - Risques d'inondation dans le delta du Fleuve Rouge. De la nécessité d'améliorer leur prise en compte dans le processus d'aménagement du territoire, Hérodote, La Découverte, 2e trimestre 121 (2006) 13pp. 